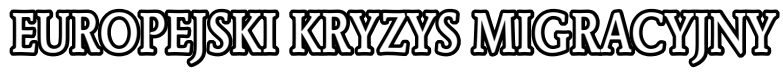 (ROZWAZANLA BOZBAWZONE ENOCDS

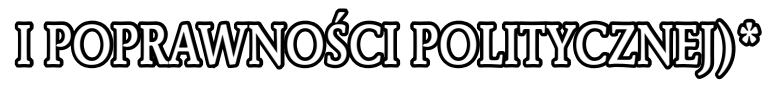

Słowa kluczowe: migracja, Europa, 2015

Keywords: Migration, Europe, 2015

Abstract: The article looks at the migrant crisis, which reached full flow in 2015, in terms of Europe's long-term development and its relationship to other continents. It verifies the limited options for studying this topic due to the unavailability of primary sources.

Temat kryzysu migracyjnego, który rozgorzał na dobre w 2015 r. wywołuje wiele kontrowersji, oświadczeń politycznych i silnych emocji. I trudno się temu dziwić, gdyż widok małych dzieci, które utonęły w morzu z jednej strony i porozrywanych ciał po eksplozji ładunków wybuchowych na ulicach europejskich metropolii ze strony drugiej potęguje emocje i sprawia, że przybierają na sile. Jednak wykorzystywanie emocji w procesie głębszego poznania problemu byłoby kontraproduktywne. Skuteczniejsza może się okazać dyskusja naukowa, która nie ulega ani wpływowi emocji, ani zasadom jałowej poprawności politycznej, czyli krytyczna analiza, która próbuje zajrzeć pod powierzchnię współczesnych zdarzeń.

${ }^{1}$ Niniejszy tekst jest nieco poszerzoną wersją wystąpienia wygłoszonego w siedzibie Akademii Nauk Republiki Czeskiej w Pradze (19 IV 2016) podczas otwarcia czesko-niemieckiej debaty na temat problematyki migracyjnej. Rozprawa została przetłumaczona na język polski przez Elżbietę Baron. 
Naukowcy mają w znacznym stopniu ograniczone możliwości rozwiązywania poważnych problemów geopolitycznych i geoekonomicznych. Jednak badacze mogą się przyczynić do ogólnej charakterystyki współczesnych zdarzeń, ich uwarunkowań i być może także do wskazania alternatyw rozwoju. W danym przypadku mogą wskazać, że migranci (to szersze pojęcie obejmuje zarówno imigrantów ekonomicznych, jak i uchodźców, których życie faktycznie jest zagrożone), tak samo jak aktywiści, zarówno ci, którzy ich wspierają, jak też ci, którzy odmawiają im pomocy, są tylko małymi pionkami na ogromnej szachownicy historii współczesnej; że często są nieświadomymi ofiarami w mechanizmie wielkiej gry strategicznej.

To bardzo szeroki i skomplikowany temat; zatem próba przedstawienia tej problematyki w zarysie nie może być wyczerpująca, a zasygnalizowanie możliwych rozwiązań nie zamierza w jakikolwiek sposób ograniczać dalszej dyskusji.

\section{Możliwości poznania}

Możliwości badań nad mającymi miejsce współcześnie zjawiskami są dalekie od optymalnych. Z uwagi na złożoność tego tematu niezbędna jest współpraca wielu dziedzin i specjalistów zajmujących się poszczególnymi regionami, przy czym żaden z tych specjalistów nie może sobie rościć prawa do całościowej charakterystyki sytuacji. Temat jest przedmiotem wojny informacyjnej, gdzie celowo szerzy się jednostronne, zniekształcone lub fałszywe informacje, które bez dostępu do źródeł pierwotnych bardzo trudno zweryfikować; często jest rzeczą konieczną analizowanie raczej symptomów zjawisk niż ich istoty.

Niemcy odgrywają w tym kryzysie kluczową rolę. Zresztą niemiecki socjolog i politolog Ulrich Beck już podczas wcześniejszego kryzysu finansowego, związanego z niewypłacalnością Grecji i z niemieckimi działaniami regulacyjnymi, doszedł do wniosku, że zamiast „europejskich Niemiec“, w minionym dziesięcioleciu, powstała „niemiecka Europa“ będąca pod silnym wpływem niemieckich interesów narodowych i specyficznej hegemonistycznej polityki; nawiązując do jej przedstawicielki i odwołując się do renesansowego teoretyka polityki, zwolennika twardej władzy absolutnej 
monarchy nazwał ją merkiawelizmem ${ }^{1}$. Jeśli zatem nawiążemy do prac niemieckich badaczy, to staniemy przed problemem komunikacji tamtejszych polityków nie tylko z krajową (niemiecką) opinią publiczną, ale też z krajami partnerskimi w ramach Unii Europejskiej; zwłaszcza w tych stosunkach uwidaczniają się wyraźne rysy wzajemnej obcości. Także niemiecki teolog ewangelicki Wolfgang Huber w swoim nowym dziele syntetycznym o etyce dopuszcza istnienie zjawiska przesycenia polityki kłamstwem tam, gdzie chodzi o kontrowersyjny temat i słusznie stwierdza, że właśnie stąd bierze się zniechęcenie polityką ${ }^{2}$. Skądinąd już Hannah Arendt w swoich esejach „Wahrheit und Lüge in der Politik“, stwierdzała, że „kłamstwo zawsze było uważane za środek dopuszczalny w polityce “3. Chodzi jednak o jego skalę, zwłaszcza w sytuacjach przełomowych. A także o świadomość, że o wiele bardziej niebezpieczna niż ewidentne kłamstwo jest taka selekcja i takie zniekształcanie danych, które w zamiarze służenia interesom politycznym wiodą na bezdroża i programowo wprowadzają w błąd opinię publiczną.

\section{Sprzeczności i pytania}

Jeden z podstawowych problemów deklaracji politycznych o migracji wynika $z$ dwóch - rzeczowo i genetycznie - zasadniczo sprzecznych motywów przyjmowania migrantów. $Z$ jednej strony jest to twierdzenie, że ich przyjęcie jest obowiązkiem państw europejskich, wynikającym w zasadzie z miłosierdzia mającego oparcie $w$ systemie prawnym. Pozostawmy tu na boku fakt, że nowoczesne prawo nie jest jakimś w sposób metafizyczny wyznaczonym kanonem, ale zmienia się - aczkolwiek z pewnym opóźnieniem w stosunku do zdarzeń - w zależności od okoliczności społecznych i politycznych, musi zatem reagować także na zasadniczą zmianę ruchów migracyjnych i na ryzyko, na które są narażone kraje będące celem nieregulowanej migracji. Wystarczy wspomnieć, że w przypadku masowej migracji nie może chodzić o automatyczny obowiązek (niedobrowolnie) przyjmujących krajów, o czym świadczy

\footnotetext{
${ }^{1}$ U. Beck, Das deutsche Europa. Neue Machtlandschaften im Zeichen der Krise, Berlin 2012.

2 W. Huber, Ethik. Die Grundfragen unseres Lebens von der Geburt bis zum Tod, München 2013, zwłaszcza w rozdziale 15, który poświęcony jest wzajemnym odniesieniom i oddziaływaniom polityki, władzy i moralności.

${ }^{3}$ H. Arendt, Wahrheit und Lüge in der Politik. Zwei Essays, München 1987, s. 8.
} 


\section{cała historia Europy, a także pragmatyczne podejście innych państw cywi- lizacji euroamerykańskiej, takich jak USA czy Australia; właśnie one jedno- znacznie wyżej postawiły własne bezpieczeństwo od dążeń do otwarcia gra- nic dla imigrantów ${ }^{4}$.}

${ }^{4}$ Następujące rozważania opierają się zarówno na faktografii zawartej w licznych opracowaniach historycznych, których opisów bibliograficznych w tym zwięzłym artykule o charakterze ogólnym nie ma większego sensu podawać, jak również na aktualnych informacjach dostarczanych przez agencje prasowe AFP, AP, ČTK, DPA, ITAR-TASS, PAP i Reuters, a także na przeprowadzonej analizie czeskiej i zagranicznej prasy. Ze względu na to, iż aktualny kryzys migracyjny wywołuje przede wszystkim szereg pytań dotyczących wzajemnego stosunku pomiędzy cywilizacją chrześcijańską i muzułmańską, względnie również między Europą, Azją i Afryką, podaję w tym miejscu chociaż niewielki wybór z ogromnej literatury przedmiotu dotyczącej tejże problematyki: P. Barša, Západ a islamismus. Střet civilizací, nebo dialog kultur?, Brno 2001; M. Bárta, M. Kovář et alii, Civilizace a dějiny. Historie světa pohledem dvaceti českých vědců, Praha 2013; M. Bárta, M. Kovář et alii, Kolaps a regenerace: cesty civilizací a kultur. Minulost, součastnost a budoucnost komplexních společností, Praha 2011; O. Beránek, Saúdská Arábie mezi tradicemi a moderností, Praha 2007; I. Buruma, Murder in Amsterdam. The Death of Theo van Gogh and the Limits of Tolerance, London 2008; F. Cardini, Europa e Islam. Storia di un malinteso, Roma - Bari 1999; M. Čejka, Encyklopedie blízkovýchodního terorismu, Brno 2007; F. M. Denny, Islam and the Muslim Community, San Francisco 1993; M. A. Ekrem, Civilizaţia turcă, Bucureşti 1981; S. Faroqhi, Kultur und Alltag im Osmanischen Reich. Vom Mittelalter bis zum Anfang des 20. Jahrhunderts, München 1995; S. Faroqhi, Geschichte des Osmanischen Reiches, München 2001; N. Ferguson, Civilization. The West and the Rest, New York 2011; E. Gombár, Moderní dějiny islámských zemí, Praha 1999; M. Hanuš (ed.), Máme se bát islámu? Západ a islám, Praha 2006 (= Revue Prostor, No. 69-70); M. Hrubec (ed.), Between Islam and the West. The Iranian Perspectives, Prague 2009; S. P. Huntington, The Clash of Civilisations, New York 1997; H. Inalcik, The Ottoman Empire. The Classical Age 1300-1600, London 1994; L. Kropáček, Duchovní cesty islámu, Praha 1993; L. Kropáček, Islám a Západ. Historická pamět' a současná krize, Praha 2002; P. Lunde, Islam, London 2002; F. Majoros, B. Rill, Das Osmanische Reich 1300-1922, Augsburg 2000; M. Mendel, Z. Müller, Svět Arabů, Praha 1989; M. Mendel, B. Ostřanský, T. Rataj, Islám v srdci Evropy. Vlivy islámské civilizace na dějiny a současnost českých zemí, Praha 2007; Z. Müller, Islám, Praha 1997; Z. Müller, Svaté války a civilizační tolerance, Praha 2005; O. Neužil, A. Mizerová (eds.), Islám a jeho svět, Brno 1995; H. Pavlincová et alii, Judalismus - Křest’anství - Islám, Praha 1994; E. W. Said, Orientalism: Western Conception of the Orient, London 1995; T. Sarrazin, Deutschland schafft sich ab. Wie wir unser Land aufs Spiel setzen, München 2011; R. Schulze, Geschichte der islamischen Welt im 20. Jahrhundert, München 2002; I. Shapiro, Containment: Rebuilding a Strategy Against Global Terror, Princeton 2007; P. Sládek et alii, Křest'anství a islám v liberálním státu. Výzvy tradice a současnosti, Červený Kostelec 2011; R. Spencer, Islam Unveiled, San Francisco 2002; P. Štěpánek, 1453: Pád Konstantiopole - zrod Istanbulu, Praha 2010; F. Tauer, Svět islámu. Jeho dějiny a kultura, Praha 1984; I. Waraq, Why I am not a Muslim, New York 1995; A. Wheatcroft, Nevěŕící. Střety křest’anstva s islámem v letech 638-2002, Praha 2006; Z. Zudová-Lešková et alii, Resettlement and Extermination of the Populations. A Syndrome of Modern History, Prague 2015. 
W ostrej sprzeczności z miłosierdziem czy solidarnością pozostaje twierdzenie, że Europa ma niski współczynnik urodzeń (natalita), a zatem potrzebuje nowej siły roboczej, która będzie zarabiać na emerytury starzejącego się społeczeństwa europejskiego. Ten pragmatyzm ekonomiczny postrzega imigrantów jako dodatkową siłę roboczą, która już od pół tysiąclecia włączana jest $\mathrm{w}$ usługi gospodarki zachodnioeuropejskich metropolii w postaci czarnych niewolników, imigrujących robotników, jeńców wojennych, w skrajnym przypadku więźniów obozów koncentracyjnych, niedawno gastarbeiterów lub wykorzystywanej na odległość taniej siły roboczej we wschodniej połowie Europy czy w Azji.

Nie miłosierdzie, ale optymalizacja zysku jest siłą napędową fali migracyjnej, która ma dwie podstawowe możliwości: albo przekracza (celowo) otwarte drzwi, albo wnika do kontrolowanej przestrzeni w sposób nielegalny czy wręcz brutalny. Współcześnie Europa bez wyraźnie zadeklarowanej wizji przyszłości znajduje się między dwiema skrajnościami. Tkwi między oświadczeniami pełnymi szlachetnych ideałów i wykorzystywaniem częściowych interesów materialnych. Za stosunkiem dużych korporacji do migrantów skrywa się czysty pragmatyzm, których napływ stwarza dla nich korzystną sytuację na rynku pracy; pragmatyczny jest oczywiście stosunek rządów do korporacji jako do największej siły napędowej gospodarki; pragmatyczne są decyzje gangów przemytników, które w handlu ludźmi znalazły kopalnię złota; pragmatyczne jest też zachowanie migrantów, którzy nie chcą zostać w pierwszym bezpiecznym kraju, ale starają się dotrzeć do najbogatszych krajów Europy. Zapewne przy podejmowaniu przez nich decyzji odgrywają także rolę inne względy, jakimi są dążenie do włączenia się w istniejące już sieci społeczności imigrantów i preferowanie „dużych“ języków (powiedzmy języka angielskiego i niemieckiego) w przeciwieństwie do „małych“ (języka polskiego lub czeskiego), które migranci mieliby sobie w nowej ojczyźnie przyswoić. Jak wynika z doświadczeń Polski i Czech, przy podejmowaniu pragmatycznej decyzji nie ma różnicy między chrześcijańskimi a muzułmańskimi uciekinierami, co często potwierdza tezę, że tu nie chodzi o ratowanie życia (choćby dlatego, że walki nie przebiegają na całym obszarze Syrii czy Iraku i że byłoby możliwe znalezienie tymczasowego schronienia w krajach geograficznie bliższych), ale o poszukiwanie korzyści socjalnych, zatem o migrację ekonomiczną. 
Sprzeczne jest także uzasadnienie polityczne przyjmowania migrantów. Znajduje to odzwierciedlenie w zmiennym postrzeganiu przez czołowych polityków migrantów jako osoby nadajace się do trwałej integracji czy odwrotnie do tymczasowej ochrony. Pragmatyzm ekonomiczny prowadzi polityków do tego, że marginalizują możliwość dodatkowej ochrony i na czoło wysuwają integrację, czyli wpływanie na rynek pracy w Europie.

Szczególnie zauważalna jest niechęć do poruszenia kwestii dotyczącej zdolności absorpcyjnej Europy w czasie eksplozji demograficznej w Afryce i niektórych częściach Azji. Teza o udzieleniu pomocy wszystkim ludziom cierpiącym z powodu prześladowań, wojny, głodu czy suszy w czasie, kiedy na świecie pojawiają się stale nowe pola walki i strefy konfliktów, i kiedy liczba „people in need“ osiąga astronomiczne wartości, jawi się jako dążenie do zanegowania realnych, zatem ograniczonych absorpcyjnych możliwości stosunkowo małego kontynentu europejskiego.

Nauki humanistyczne i społeczne powinny jednak zadać sobie także wiele innych pytań i pokusić się o zajęcie jasnego stanowiska wobec niektórych tez politycznych i medialnych, które mają dla realistycznego zrozumienia kryzysu migracyjnego kluczowe znaczenie; powinny sprawdzić prawdziwość twierdzeń, takich jak: współczesna fala migracyjna zwiększa ryzyko/ nie zwiększa ryzyka terroryzmu i konfliktów w Europie; koncentracja imigrantów muzułmańskich w krajach europejskich tworzy zaplecze/nie tworzy zaplecza dla działalności terroryzmu islamskiego; udzielenie pomocy dzieciom migrantów z pobudek humanistycznych w kolejnych dziesięcioleciach będzie powodem/nie będzie powodem ich frustracji z powodu nierównorzędnej pozycji w społeczeństwie europejskim, w wyniku czego może stanowić nowy potencjał/nie może stanowić nowego potencjału konfliktów między społeczeństwem większościowym a mniejszością; czy Europa potrafi/czy nie potrafi zapewnić milionom imigrantów takiego poziomu życia, aby się naprawdę zintegrowali; przybysze zwłaszcza z krajów islamskich mają wolę/ nie mają woli i ochoty do przyjęcia europejskiego stylu życia i podporządkowania się normom prawnym krajów europejskich; współczesny system polityczny Europy potrafi/nie potrafi się skutecznie przeciwstawić rozkładowi w konfrontacji z silną falą migracyjną, ciągłemu zagrożeniu terrorystycznemu i jednocześnie fali narastającego prawicowego i lewicowego ekstremizmu, dla którego załamywanie się standardów bezpieczeństwa w Europie stanowi podatny grunt; i tak moglibyśmy kontynuować to wyliczanie. $\mathrm{O}$ ile 
przyjmie się, że nacisk migracyjny na Europę stanie się zjawiskiem długofalowym, to jest rzeczą bardzo prawdopodobną, że tego rodzaju pytania nie staną się jedynie przedmiotem zainteresowania polityków, analityków ds. bezpieczeństwa i poszczególnych badaczy, ale że zasadniczo wpłyną na wybór preferowanych tematów badawczych w dziedzinie dyscyplin humanistycznych i społecznych.

\section{Europejskie doświadczenie cywilizacyjne i jego dualizm}

Unia Europejska zareagowała na kryzys migracyjny w duchu haseł „wartości“ europejskich. Pojęcie to nie jest jasno zdefiniowane, jest ono odmiennie postrzegane przez praktykujących i bezwyznaniowych chrześcijan, agnostyków i ateistów, różne grupy interesów wypełniają je różną treścią. Fiaskiem zakończona próba uchwalenia Konstytucji dla Europy świadczy o tym, że obowiązująca definicja wspólnych wartości jest we współczesnej Europie czystą iluzją. Bardziej możliwe do uchwycenia wydaje się być raczej pojęcie europejskiego doświadczenia cywilizacyjnego. Jest to ogromny bagaż stuletnich doświadczeń, przeżyć i informacji, o których obywatele zapominają, a politycy jedynie wybiórczo je przypominają, ale które są w nas i w sytuacjach kryzysowych ujawniają się nieoczekiwanie. Europejskie doświadczenie cywilizacyjne tworzy dziedzictwo antyku, judaizmu i chrześcijaństwa ze wszystkimi jego jasnymi i ciemnymi stronami, ogromne dziedzictwo kulturowe i intelektualne średniowiecza, renesansu, oświecenia i innych inspirujących epok, przełomowe rewolucje agrarna, przemysłowa i komunikacyjna, tak samo jak kolonializm i rasizm, komunizm, faszyzm, nazizm i holocaust. Jest to dziedzictwo rozmachu i budowania, wojen i niszczenia, ale też zaciętych walk o samozachowanie Europy, począwszy od wojen grecko-perskich, przez obronę przeciwko arabskim podbojom w średniowieczu, aż po trwające kilka stuleci wojny o charakterze egzystencjalnym przeciwko destrukcyjnej ekspansji tureckiej.

Zasadnicze rysy doświadczenia cywilizacyjnego są wspólne dla wszystkich Europejczyków. Równocześnie jednak doświadczenie to jest wewnętrznie rozczłonkowane nie tylko w sensie narodowym i społecznym, ale przede wszystkim z uwzględnieniem dualizmu Europy. Dualizm ten jest obiektywną konsekwencją zróżnicowanego rozwoju w minionych pięciuset latach, 
a zwłaszcza w XX w. W pojedynczych kwestiach, czasem bardzo ważnych, doświadczenia krajów Europy Zachodniej (postkolonialnych) różnią się od doświadczeń krajów Europy Wschodniej (posttotalitarnych). W przeciwieństwie do mocarstw morskich na zachodzie Europy (łącznie z Niemcami) kraje Europy Środkowej i Wschodniej (ze szczególnym wyjątkiem Rosji) nigdy nie uczestniczyły w ekspansji kolonialnej i mordowaniu ludności tubylczej w krajach zamorskich, nie zdobyły podobnego bogactwa ani globalnych doświadczeń i po rozpadzie systemu kolonialnego nie stały się odbiorcami imigrantów z dawnych kolonii. Wręcz przeciwnie, doznały gorzkich doświadczeń okupacji tureckiej, austriackiej, niemieckiej, rosyjskiej i sowieckiej, niektóre $z$ nich w czasie II wojny światowej były zagrożone całkowitym unicestwieniem przez reżim nazistowski. Oczywiście nie oznacza to, że narody te nie miały w swojej historii ciemnych plam, gdyż nie ma kryształowo czystej przeszłości.

Nie ulega jednak wątpliwości, że mieszkańcy posttotalitarnej części Europy nie brali udziału w podbojach kolonialnych, ludobójstwie i grabieżach, a co za tym idzie, nie mają tego rodzaju długu wobec narodów dawnych kolonii. Peryferyjna pozycja w Europie w okresie wzrostu jej dominacji nad światem znacznie zmniejszyła ambicje narodów w środkowej i wschodniej części kontynentu, ale jednocześnie wyposażyła je w większą czujność na groźbę dyktatu i wymuszonych zmian, łącznie z przymusową imigracją. Pogardliwy stosunek zachodnich polityków wobec nich wynika nie tylko z kompleksu mocarstwowego, ale przede wszystkim z niezrozumienia tego odmiennego doświadczenia historycznego, które siłą rzeczy musiało się przejawić w konfrontacji z kryzysem migracyjnym.

Płytkie potępianie domniemanej ksenofobii społeczeństw wschodnioeuropejskich całkowicie pomija fakt, że w ich krajach doszło do dobrowolnej i bezproblemowej integracji nie tylko Ukraińców, ale też Wietnamczyków i innych mniejszości narodowych. Bez gett, bez „wrażliwych stref miejskich“ (zwanych też strefami no-go) i bez terroryzmu. Nasuwa się zatem pytanie, czy zachodnia część Europy doceni to zmodyfikowane doświadczenie i jego konsekwencje dla postępowania państw we wschodniej połowie Unii Europejskiej jako wzbogacenie ogólnego europejskiego doświadczenia, czy też będzie dążyć do jego bezwzględnego stłumienia, co sugeruje sposób negocjacji w sprawie kwot podziału migrantów. 


\section{Zagrożenia}

Nauki humanistyczne i społeczne powinny przyczyniać się do przekazywania opinii publicznej rzetelnych (aczkolwiek nieprzyjemnych) informacji i tym samym zapobiegać powstawaniu panicznego strachu, który pojawia się tam, gdzie panuje niewiedza i gdzie wyjdzie na jaw kłamliwość zapewnień, że właściwie nic poważnego się nie dzieje. Trzeba znać możliwe ryzyka, przygotować się do nich i w miarę możliwości im zapobiegać. Analitycy ds. bezpieczeństwa (łącznie z Europolem) są pod tym względem bardziej uczciwi, ponieważ znajdują się na pierwszej linii zmagań $z$ realnymi zagrożeniami, a ci ostrzegają: (1) skończyły się czasy, kiedy Europejczycy mogli się czuć bezpiecznie; współcześnie nikt nie wie, kiedy i gdzie dojdzie do kolejnego ataku terrorystycznego i masowego mordowania Europejczyków; (2) istnieją grupy przestępcze zajmujące się przemytem ludzi, który stał się jednym z najbardziej dochodowych zajęć, zyski z tego procederu wynoszą rocznie miliardy euro; stworzyły one zaawansowaną infrastrukturę od Belgii po Tajlandię, na początku 2016 r. liczącą około 40 tys. pracowników i bardzo umiejętnie wykorzystują luki w obronie europejskiej, w systemie prawnym i politycznym; (3) gangi imigrantów, które mają zaplecze społeczne w miejscach o wysokiej koncentracji migrantów, tworzą nową sieć europejskiej przestępczości; mają duże możliwości werbowania spośród sfrustrowanych migrantów i ich potomków z drugiej i trzeciej generacji.

Nie chodzi jednak tylko o oczywiste ryzyko dotyczące bezpieczeństwa. Kryzys migracyjny odkrył także inne zagrożenia: (1) Powstały ad hoc sojusze bezpieczeństwa i nowe napięcia: Sojusz części lewicy, propagującej niemal nieograniczone otwarcie granic i części prawicy, wspierającej optymalizację zysku na korzyść dużych korporacji; sojusze niektórych państw północnych rozwiązujących swój deficyt demograficzny i niektórych państw południowych zalanych falą migrantów. Zainteresowane kraje swoje narodowe interesy prezentują jako interesy „europejskie“ i starają się je narzucić wszystkim członkom Unii Europejskiej, co bardzo osłabia jej spójność. (2) Obrona zewnętrznych granic Unii Europejskiej jest karygodnie zaniedbywana, także kroki ratunkowe muszą podjąć poszczególne - także nieczłonkowskie - państwa Europy. Ustępstwa wobec Turcji, która ma „bronić“ Europę, ale przy tym autorytarnie ingeruje $\mathrm{w}$ wewnętrzne sprawy europejskie, przynoszą kolejny potencjał erozyjny. (3) Reakcja na falę migracyjną poddała 
w wątpliwość porządek prawny Europy. Pokazała, że można pod naciskiem silnych państw chwilowo zawiesić obowiązywanie niektórych praw i przyjęte normy postępowania. Nacisk na kwoty i holistyczne podejście do rozwiązywania problemów migracyjnych na świecie, proklamowane przez część Parlamentu Europejskiego dały do zrozumienia, że ma zostać zakwestionowane także podstawowe prawo państw członkowskich Unii Europejskiej, jakim jest decydowanie o wielkości napływu obcokrajowców na terytorium poszczególnych państw. (4) Sprzeczność między prawem administracji brukselskiej (kierowanej oczywiście z innych ośrodków politycznych) do centralnej ingerencji w interesy egzystencjalne państw członkowskich Unii Europejskiej i niezdolnością tej administracji do zapewnienia bezpieczeństwa przynajmniej w centrum Brukseli, podważa zaufanie do Unii Europejskiej. Każde kolejne wybory w państwach Unii Europejskiej stają się poniekąd horrorem i mogą się przemienić w brunatną katastrofę. (5) Dysproporcja w podejściu do zachodnich i wschodnich reakcji na kryzys migracyjny sprawia, że pogłębia się przepaść między postkolonialnymi i posttotalitarnymi państwami Unii Europejskiej. Wraz z brakiem zdolności Unii Europejskiej do podjęcia obrony prowadzi to do spontanicznej militaryzacji państw, uzbrojonych grup i pojedynczych osób. (6) Jeśli fala migracji nie zostanie powstrzymana, to może się zdarzyć, że sfrustrowani Europejczycy, a czasem także grupy paramilitarne będą toczyć walki z migrantami i z gangami imigrantów. Te mogłyby odpowiedzieć kolejnymi atakami terrorystycznymi i uruchomić spiralę niekontrolowanego zabijania. $\mathrm{W}$ takiej sytuacji istniejące siły wojskowe i siły bezpieczeństwa państw europejskich nie potrafiłyby chronić równocześnie granic, większych miast i ważnych obiektów ryzyka. Państwa europejskie byłyby coraz bliżej totalnego chaosu i stanu wojny domowej.

\section{Rozwiązania}

W długofalowej perspektywie historycznej współczesna sytuacja wydaje się być bardzo poważna, natomiast reakcja europejskich polityków niedostateczna. Nie powinniśmy jednak ulegać rozpaczy i deterministycznemu wyobrażeniu, że kryzys migracyjny jest katastrofą naturalną, wobec której ludzie są absolutnie bezradni. W świetle nowych doświadczeń - przynajmniej z punktu widzenia historyka - wysuwają się na pierwszy plan także możliwe 
pozytywne rozwiązania, o ile Europa wykorzystałaby swoje historyczne doświadczenia i postanowiłaby postępować z racjonalną pewnością siebie:

(1) Unia Europejska może odejść od dotychczasowej problematycznej linii centralistycznej i powrócić do modelu dobrze funkcjonującej wspólnoty gospodarczej w postaci, która odpowiadałaby zarówno Wielkiej Brytanii, jak też państwom we wschodniej części Unii Europejskiej.

(2) Korzystając z doświadczeń NATO, Unia Europejska może zbudować własny system obrony i kontroli zewnętrznych granic, aby pozbyć się upokarzającej pozycji zakładnika Turcji i państw północnoafrykańskich.

(3) Państwa europejskie, które chca zwiększyć liczbę mieszkańców, mogą regulować migracje zgodnie ze swoimi potrzebami, nieobciążając przy tym pozostałych państw; mogą ustalić dla siebie kwoty (na wzór Austrii), wybierać migrantów poza Europą i drogą lotniczą transportować na przykład bezpośrednio do Niemiec; z pewnością byłoby to bardziej humanitarne, bezpieczniejsze i tańsze niż dodatkowe sprawdzanie samowolnie przybywających migrantów i przymusowe odsyłanie części z nich z powrotem do Afryki czy Azji.

(4) Unia Europejska powinna na nowo i bardziej odpowiedzialnie niż do tej pory przemyśleć swoją tożsamość, następnie zmodyfikować także jej ramy prawne i instytucjonalne, które odpowiadałyby realnej sile Europy i jej pozycji w świecie XXI w.; oznaczałoby to odejście od pozostałości neokolonializmu, zwłaszcza stwarzania pozorów odpowiedzialności za cały świat; konsekwentna świadomość odpowiedzialności przede wszystkim za własnych obywateli, choćby nawet przy zachowaniu możliwego do zaakceptowania stopnia solidarności $z$ innymi kontynentami; sformułowanie zasady, że nie tylko za rozwiazywanie wewnętrznych konfliktów w Azji czy Afryce, ale także za regulację tamtejszej eksplozji demograficznej niosq odpowiedzialność w pierwszym rzędzie państwa i kontynenty, $w$ których problemy te powstają.

Europa oczywiście nie może się hermetycznie zamknąć wobec pozostałych kontynentów, ale jeśli wykaże wolę, to ma możliwość regulować imigrację w sposób dostosowany do jej możliwości i potrzeb; jednak wobec swoich obywateli ma obowiązek zminimalizowania zagrożeń, jakie docierają z innych kontynentów. Europa po raz kolejny znajduje się na dziejowym rozdrożu - albo aktywnie weźmie swój los w swoje ręce lub będzie tylko biernym 
uczestnikiem wydarzeń, w wyniku czego może dojść do rozkładu cywilizacji europejskiej. Kryzys migracyjny odkrył to w całej pełni, ale pozytywne rozwiązanie ciągle jeszcze jest w zasięgu możliwości Europejczyków.

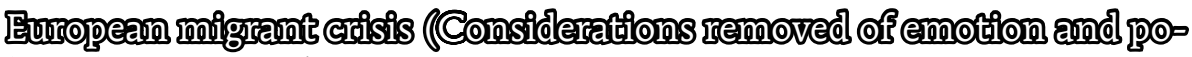 lifificall corsectroess)}

The article looks at the migrant crisis, which reached full flow in 2015, in terms of Europe's long-term development and its relationship to other continents. It verifies the limited options for studying this topic due to the unavailability of primary sources. It analyses fundamental contradictions in the current political and journalistic presentation of the topic, in particular the contradiction between the proclamation of legally secured grace, and the attempt to make up the workforce deficit; between temporary protection and permanent integration of migrants. It emphasises the pragmatic features of the actions of large economic corporations, governments, trafficking gangs and migrants. Against this, it notes the need to determine Europe's absorption abilities and rigorously support the population of Africa and Asia remaining in their home nations, but with a regulated birth rate (implementing a planned parenthood model), and with greater support from richer Arab countries. Instead of the ambiguous concept of 'European values', it formulates the notion of European civilisation experience and its duality, which is conditional upon a different approach to immigration in Western (post-colonial) and Eastern (post-totalitarian) states within the European Union. In conclusion, it outlines the threats unmanaged migration represents for Europe, and the potential for managing this crisis. 